\title{
Phytochemical, Anti-inflammatory and Analgesic Studies of the Crude Ethanolic Leaf Extract of Globimetular brounii Van Tieghem (Family: Loranthaceae)
}

Atiku I*, Sule MI, Pateh UU, Musa AM, Ya'u J, Sani YM, Hanwa UA, Abdullahi SM, Adamu SA, Lawal EA and Abdulrahman H

Department of Pharmaceutical and Medicinal Chemistry, Ahmadu Bello University, Zaria, Nigeria

\begin{abstract}
Globimetula braunii is a bushy parasitic plant growing on Terminalia catappa, which has a variety of use in African traditional medicine. The leaves of the plant was subjected to preliminary phytochemical analysis, Acute Toxicity studies and analgesic activity using Hot plate and acetic acid induced pain method in mice, while the anti-inflammatory activity was tested using Carrageenan-induced paw oedema in rats. The Phytochemical analysis of the ethanolic leaf extract of Globimetula braunii revealed the presence of Carbohydrate, Steriods, Triterpenes, Tannins, Saponins, Alkaloids and Flavonoids; The $\mathrm{LD}_{50}$ was found to be greater than $5000 \mathrm{mg} / \mathrm{kg}$ which shows that the plant extract is relatively safe. The results from the Hot-plate method showed that the extract was statistically significant at $(p<0.02$ and $p<0.01)$, this shows that there is increase in the latency of pain in the extract compare to standard drug pentazocine $(20 \mathrm{mg} / \mathrm{kg})$, while the Acetic acid induced method the extract was statistically significant at $(\mathrm{p}<0.02)$ with a percentage of inhibition of $65.5 \%, 65.2 \%$, and $67.7 \%$ at the doses of $12.5 \mathrm{mg} / \mathrm{kg}, 25 \mathrm{mg} / \mathrm{kg}$, and $50 \mathrm{mg} / \mathrm{kg}$ compared with the standard drug piroxicam $(10 \mathrm{mg} / \mathrm{kg}$ ) with a percentage inhibition of $54.3 \%$. The extract was also found to significantly $(P<0.05)$ inhibit oedema at all doses: $250 \mathrm{mg} / \mathrm{kg}, 500 \mathrm{mg} / \mathrm{kg}$ and $1000 \mathrm{mg} / \mathrm{kg}$. This shows that the plant contains phytochemical constituent with analgesic and anti-inflammatory activities.
\end{abstract}

Keywords: Globimetula braunii; Phytochemical; Analgesic activity; Anti-inflammatory

\section{Introduction}

Medicinal herbs have been used as a form of therapy for the relief of pain throughout history [1]. The treatment of rheumatic disorder is an area in which the practitioners of traditional medicine enjoy patronage and success. Natural products in general and medicinal plants in particular, are believed to be an important source of new chemical substances with potential therapeutic efficacy [2]. Pain has is defined as an unpleasant sensory and emotional experience associated with actual or potential tissue damage. It is always a warning signal and primarily protective in nature but often causes a lot of discomfort and lead to many adverse effects [3]. The plant Globimetula braunii (Engler) Van Tieghem (Family: Loranthaceae) is a semi-parasitic shrubs that grows on various trees with woody stem. The leaves are simple, leathery and evergreen. It attaches itself to the host by woody suckers often regarded as adventitious roots. It is distributed mainly in the tropics, but also found in the temperate regions [4]. The plant is a common sight in many parts of West Africa, particularly in plantation of cocoa (Theobroma cacao), kola (Cola acuminata) and Terminalia catapa where wide branches are often covered with this pest [5]. It is commonly called mistletoe. Yoruba people of south west Nigeria called it Afono onishano, while Hausa speaking people of Northern Nigeria called it Kauchi [6]. In developing countries like Nigeria where conventional health care is not given adequate attention, $G$. braunii is used by traditional healers in to treat various diseases such as cardiovascular diseases, diabetes, headache, chest pain, leg pain, pulmonary problems and sickle cell anaemia [6]. Previous studies showed that the leaves of the plant contains Tannins, anthraquinone, alkaloids, steroids, saponins, and cyanogenetic glycoside [7,8] Although there is a paucity of information on the biological activities of this species, biological studies of $G$. braunii growing on some host plants were reported which include hypoglycaemic effect [9], and antioxidant effect [10]. To the best of our intensive literature search, this plant has not been investigated for analgesic potential despite the folkloric claims. Therefore, this research work aims at establishing scientific basis for the folkloric use of the plant as an analgesic agent.

\section{Collection and identification of materials}

The leaves of G. braunii growing on Terminalia catapa were collected in the month April, 2013, at the fields of Ahmadu Bello University Zaria, Nigeria. The plant was identified by Mallam U.S. Gallah of the Herbarium Unit, Department of Biological Sciences, Ahmadu Bello University Zaria, Nigeria, (Voucher specimen number 007). The plant material was air dried under shade until constant weight was obtained and size reduced manually using clean mortar and pestle.

\section{Preparation of the extract}

$250 \mathrm{~g}$ of the plant material was subjected to cold maceration using $75 \%$ water for 24 hours. Then the extract was filtered using Whatman Filter paper (No. 1) and the filtrate was evaporated under reduced pressure and dried to afford $8.20 \mathrm{~g}(\% \mathrm{w} / \mathrm{w})$ of a brownish residue referred to as Crude Ethanol Extract.

\section{Phytochemical screening}

Preliminary qualitative phytochemical tests were carried out on Crude Ethanol Extract employing standard procedures [11].

\section{Animals}

Swiss albino mice of either sex weighing 20-25 g were obtained from the Animal House, Department of Pharmacology and Therapeutics, Faculty of Pharmaceutical Sciences, Ahmadu Bello University, Zaria

*Corresponding author: Atiku Ibrahim, Department of Pharmaceutical and Medicinal Chemistry, Ahmadu Bello University, Zaria, Nigeria, Tel: 07039605662; E-mail: el_ibat@yahoo.com

Received August 31, 2015; Accepted September 30, 2015; Published October 07, 2015

Citation: Atiku I, Sule MI, Pateh UU, Musa AM, Ya'u J, et al. (2015) Phytochemical, Anti-inflammatory and Analgesic Studies of the Crude Ethanolic Leaf Extract of Globimetular brounii Van Tieghem (Family: Loranthaceae). Nat Prod Chem Res 3: 193. doi:10.4172/2329-6836.1000193

Copyright: (c) 2015 Atiku I, et al. This is an open-access article distributed under the terms of the Creative Commons Attribution License, which permits unrestricted use, distribution, and reproduction in any medium, provided the original author and source are credited. 
Citation: Atiku I, Sule MI, Pateh UU, Musa AM, Ya'u J, et al. (2015) Phytochemical, Anti-inflammatory and Analgesic Studies of the Crude Ethanolic Leaf Extract of Globimetular brounii Van Tieghem (Family: Loranthaceae). Nat Prod Chem Res 3: 193. doi:10.4172/2329-6836.1000193

Page 2 of 4

Nigeria. The animals were stabilized for 1 week; they were maintained at room temperature. They were provided with standard animal feed and water throughout the course of study. The experiments were carried out between the period of 9:00 and 16:00 hours in a quite laboratory.

\section{Acute toxicity studies}

Acute toxicity studies was carried out using Lorke method (1983) and the studies was divided into two phase. In first phase, nine mice were divided into three groups of three mice each. Group I received $10 \mathrm{mg} / \mathrm{kg}$ of the extract while Group 2 and 3 received $100 \mathrm{mg} / \mathrm{kg}$ and $1000 \mathrm{mg} / \mathrm{kg}$ respectively. The mice were observed for symptoms of toxicity for the first $4 \mathrm{~h}$, then mortality for $24 \mathrm{~h}$. The second phase of this experiment was carried out based on the outcome of the first phase. Three mice were weighed and divided into three groups of one mouse each. Group 1 received extract at the dose of $1600 \mathrm{mg} / \mathrm{kg}$, while group 2 and 3 received the extract at the dose of $2900 \mathrm{mg} / \mathrm{kg}, 5000 \mathrm{mg} /$ $\mathrm{kg}$ respectively. The animals were observed for $24 \mathrm{~h}$ and the $\mathrm{LD}_{50}$ was calculated as the geometric mean of the doses for which 0 and $100 \%$ survival rate occurred [12].

\section{Acetic acid induced writhing in mice}

The method described by ref. [13] was adopted. Thirty mice were divided into five groups each containing six mice. The first group served as a negative control and received $10 \mathrm{ml} / \mathrm{kg}$, i.p. of normal saline and the second group served as a positive control group which received piroxicam $10 \mathrm{mg} / \mathrm{kg}$ i.p. The test groups were treated with $12.5 \mathrm{mg} / \mathrm{kg}$, $25 \mathrm{mg} / \mathrm{kg}, 50 \mathrm{mg} / \mathrm{kg}$ i.p. After 30 minutes of drug administration, all the groups were treated with $0.2 \mathrm{mls} 0.6 \% \mathrm{v} / \mathrm{v}$ acetic acid i.p. the number of abdominal contractions was counted for each mouse for the period of 10 minutes with a tally counter.

The percentage inhibition of abdominal contraction was calculated using this formula;

$$
\text { Inhibition }(\%)=\frac{\text { Mean no. of writhes }(\text { control })-\text { Mean no.of writhes }(\text { test })}{\text { Mean no.of writhes }(\text { Control) }} \times 100
$$

\section{Hot plate method}

The method described by ref. [14] was adopted. Thirty mice were divided into five groups each containing six mice. Group 1 served as a negative control and received $10 \mathrm{ml} / \mathrm{kg}$ of normal saline i.p. and the second group which served as a positive control group received pentazocine $20 \mathrm{mg} / \mathrm{kg}$ i.p. The test groups received 12.5, 25 and $50 \mathrm{mg} /$ $\mathrm{kg}$ i.p. respectively of the extract; the mice were placed on the hot plate maintained at $55^{\circ} \mathrm{C} \pm 1^{\circ} \mathrm{C}$. Reaction time of animals was noted down at $30,60,90,120$ and 150 mins after the treatment. The basal reaction time was taken by observing hind paw licking or jump response (whichever appear first) in animals while placed on the hot plate. A cut off period of 10 seconds was observed to avoid damage to the paws.

\section{Carrageenan-induced paw oedema}

The test was conducted according to the method described by ref. [15]. Wistar rats were divided into five groups each containing five rats. The first group received normal saline $\left(10 \mathrm{mlkg}^{-1}\right)$, i.p. Groups two, three and four were given $6.25,12.5$ and $25.0 \mathrm{mg} / \mathrm{kg}$ body weight i.p. respectively of the plant extract, while the fifth group received ketoprofen $10 \mathrm{mg}$ per $\mathrm{kg}$ i.p. $30 \mathrm{~min}$ later, $0.1 \mathrm{ml}$ of freshly prepared carrageenan suspension ( $1 \% \mathrm{w} / \mathrm{v}$ in $0.9 \%$ normal saline) was injected into the sub plantar region of the left hind paw of each rat. The paw diameter was measured with the aid of a vernier caliper at $0,1,2,3$, 4 and $5 \mathrm{~h}$, after the injection of carrageenan. The difference between the readings at time $0 \mathrm{~h}$ and different time interval was taken as the thickness of oedema.

\section{Statistical analysis}

The data were expressed as mean \pm SEM. Results were analysed statistically by One-way ANOVA followed by Tukey's multiple comparison using SPSS software. The difference was considered significant at $\mathrm{p}<0.05$.

\section{Results}

\section{Phytochemical constituents of the leaves of Globimetula braunii}

Preliminary phytochemical tests revealed the presence of flavonoids, tannins and saponins (Table 1).

\section{Analgesic effect of ethanolic leaf extract of Globimetula braunii}

Table 2 shows the results of the analgesic studies of Leaf Extract of Globimetula braunii Leaf.

Data presented as mean \pm standard error of mean with ${ }^{*}$ statistically significant at $\mathrm{p}<0.01$ and ${ }^{* *}$ are statistically significant at $\mathrm{p}<0.02$ respectively. The student's t-test $n=6$.

\section{Acetic acid induced writhing in mice}

Table 3 shows the result of acetic acid induced writhing in mice.

\section{Key: $\left(^{*}\right)=\mathrm{p}<0.02$ (significant)}

Data presented as mean \pm standard error of mean with * statistically significant at $\mathrm{p}<0.01$. The student's t-test $\mathrm{n}=6$, Normal saline control was used to compare with piroxicam and ethanolic crude extract. Anti-inflammatory effect of ethanol leaf extract of Globimetula braunii

\begin{tabular}{|c|c|}
\hline Constituents & Inference \\
\hline Carbohydrates & + \\
\hline Steroids & + \\
\hline Tannins & + \\
\hline Triterpenes & + \\
\hline Saponins & + \\
\hline Alkaloids & + \\
\hline Flavonoids & - \\
\hline Anthraquones & + \\
\hline
\end{tabular}

Table 1: Results of phytochemical analysis of leaves of Globimetula braunii. + Present; -: Absent.

\begin{tabular}{|l|l|l|l|l|}
\hline \multirow{2}{*}{ Treatment/(mg/kg) } & \multicolumn{4}{|l|}{ Mean Pain threshold (minutes) (mean \pm SEM) } \\
\hline Normal saline (10 ml/kg) & $\mathbf{0}$ & $\mathbf{3 0}$ & $\mathbf{6 0}$ & $\mathbf{9 0}$ \\
\hline Pentazocine (20) & $4.83 \pm 0.4$ & $3.17 \pm 0.4$ & $2.0 \pm 0.37$ & $3.5 \pm 0.3$ \\
\hline Extract (12.5) & $5.16 \pm 0.7$ & $2.5 \pm 0.43$ & $3.0 \pm 0.37$ & $4.67 \pm 0.76$ \\
\hline Extract (25) & $4.33 \pm 0.99$ & $3.0 \pm 0.37$ & $2.17 \pm 0.48$ & $4.0 \pm 0.26$ \\
\hline Extract (50) & $5.17 \pm 0.48$ & $2.83 \pm 0.31$ & $3.83 \pm 0.34^{*}$ & $6.0 \pm 0.71^{*}$ \\
\hline
\end{tabular}

Table 2: Analgesic effect of ethanolic leaf extract of Globimetula braunii leaf extract of Globimetula braunii.

\begin{tabular}{|c|c|c|c|}
\hline Treatment $(\mathbf{I P})$ & Dose $\mathbf{( m g / k g )}$ & Mean \pm SEM & $\%$ inhibition \\
\hline Normal saline & $10 \mathrm{ml} / \mathbf{k g}$ & $27.33 \pm 1.93^{\star}$ & 0 \\
\hline Piroxicam & 10 & $9.67 \pm 2.65^{\star}$ & 54.3 \\
\hline Extract1 & 12.5 & $9.33 \pm 2.84^{\star}$ & 65.2 \\
\hline Extract2 & 25 & $10.33 \pm 2.64^{\star}$ & 69.5 \\
\hline Extract3 & 50 & $8.83 \pm 1.99^{\star}$ & 67.7 \\
\hline
\end{tabular}

Table 3: Acetic acid induced writhing method. 
Citation: Atiku I, Sule MI, Pateh UU, Musa AM, Ya'u J, et al. (2015) Phytochemical, Anti-inflammatory and Analgesic Studies of the Crude Ethanolic Leaf Extract of Globimetular brounii Van Tieghem (Family: Loranthaceae). Nat Prod Chem Res 3: 193. doi:10.4172/2329-6836.1000193

Page 3 of 4

\begin{tabular}{|c|c|c|c|c|}
\hline Treatment Groups (mg/kg) & \multicolumn{4}{|c|}{ Mean Paw Diameter (cm) } \\
\hline Hours & $\mathbf{1 ~ h r}$ & $\mathbf{2 ~ h r}$ & $\mathbf{3 ~ h r}$ & $\mathbf{4} \mathbf{~ h r}$ \\
\hline N/Saline $(10 \mathrm{ml} / \mathrm{kg})$ & $2.52 \pm 0.42$ & $3.32 \pm 0.45$ & $3.81 \pm 0.34$ & $2.55 \pm 0.45$ \\
\hline Extract $(250)$ & $1.36 \pm 0.14(46.0)$ & $2.57 \pm 0.32(22.5)$ & $3.30 \pm 0.30(13.4)$ & $2.06 \pm 0.25(19.2)$ \\
\hline Extract (500) & $1.52 \pm 2.10(39.7)$ & $2.55 \pm 0.13(23.2)$ & $3.10 \pm 0.30(18.6)$ & $2.09 \pm 0.29(18.0)$ \\
\hline Extract (1000) & $0.60 \pm 0.11(76.2)$ & $1.55 \pm 0.40(53.3)$ & $2.02 \pm 0.56(46.9)$ & $1.23 \pm 0.48(51.8)$ \\
\hline Ketoprofen (10) & $1.12 \pm 0.21(55.5)$ & $1.32 \pm 0.20(60.2)$ & $10 \pm 0.36(45.0)$ & $1.48 \pm 0.18(42)$ \\
\hline
\end{tabular}

Table 4: Effect of Ethanol leaf extract of Globimetula braunii on Carrageenan-induced pawoedema in rats.

on carrageenan-induced paw oedema in rats (Table 4). Each value represents mean \pm SEM. $\mathrm{P}<0.05$, compared with control values for corresponding hours. Figures in parentheses represent percentage inhibition of inflammation.

\section{Discussion}

The phytochemical studies revealed that the ethanol extract of Globimetula braunii contains revealed the presence of carbohydrates, steroids, triterpenes, tannins, saponins, alkaloids, flavonoids, and antraquinones. Flavonoids, tannins and saponins have been reported to possess analgesic and anti-inflammatory activities [16,17]. It is, therefore, possible to suggest that these phytochemical constituents, found to be present in the ethanol extracts of Globimetula braunii may be responsible for the observed effects. The relatively high oral median lethal dose (LD50) in mice (greater than $5000 \mathrm{mg} / \mathrm{kg}$ ) suggests that the extract is relatively nontoxic when taken orally [12]. Drugs derived from plant origin are considered less toxic and exhibit fewer side effects compared to the synthetic ones [18]. Acetic acid induced abdominal contraction method has been used to evaluate peripherally acting analgesics. In acetic acid induced method pain is generated indirectly via endogenous mediators like prostaglandin, which stimulates peripheral nociceptive neurons. These neuronal fibers are sensitive to both narcotics and non-steroidal anti-inflammatory drugs [19]. The result of acetic acid induced method revealed that the extract treated groups have statisticaly significant effect $(\mathrm{p}<0.02)$ when compared with the normal saline group. The ethanol leave extract of Globimetula braunii had the highest percentage protection of $69.5 \%$ at the dose of $25 \mathrm{mg} / \mathrm{kg}$, at the dose of $12.5 \mathrm{mg} / \mathrm{kg}$ and $50 \mathrm{mg} / \mathrm{kg}$ it gave $65.2 \%$ and $67.7 \%$, while the standard drug (piroxicam $10 \mathrm{mg} / \mathrm{kg}$ ) gave the lowest percentage protection of $54.34 \%$. This implies that the extract have more analgesic property which can be compared to that of the standard drugs and may be useful in the treatment of pain. The result of the hot plate method showed the extract showed statistically significant $(\mathrm{P}<0.02)$ and $(\mathrm{p}<0.01$ increase in reaction time while compared to control at 60 minutes and 90 minutes when compared with the standard drug (pentazocine). This showed that pentazocine has a lower percentage inhibition than the plant extract, this might be due to the fact that pentazocine is a mixed agonist/antagonist analgesic which acts as agonist on kappa receptor and a weak opioid antagonist on $\mathrm{Mu}$ receptor [20] while the ethanolic extract of Globimetula braunii leaf might probably act on kappa and $\mathrm{Mu}$ receptor as agonist. It is an established fact that any agent which causes a prolongation of hot plate latency using this test might be acting centrally [21]. The extract caused marked inhibition of carrageenan induced oedema in rats. Carrageenan induced inflammation is believed to be biphasic, the early phase (1-2 h) is mainly mediated by histamine, serotonin and increased synthesis of prostaglandins in the damaged tissue surroundings, the late phase is sustained by prostaglandins released and mediated by bradykinin, leukotrienes, polymorphonuclear cells and prostaglandins produced by tissue macrophages [22]. The inhibitory effect of the extract $20 \mathrm{mg} / \mathrm{kg}$ on carageenan induced inflammation over period of $4 \mathrm{~h}$ is similar to the effect of most non-steroidal anti-inflammatory drugs. This suggests that it acts in later phase probably involving arachidonic acid metabolites which produce oedema dependent on neutrophils mobilization [23]. The analgesic and anti-inflammatory effect of the plant extract May therefore, be due to the presence of flavonoids, tannins, alkaloid or saponins [24-25]. However, further studies are in progress in our laboratory to isolate the active constituents responsible for the observed effect, and to elucidate the possible mechanisms of action responsible for the analgesic and anti-inflammatory activities of the methanolic leaf extract.

\section{Conclusion}

In conclusion, the results of the study showed that the extract of Globimentula braunii has both analgesic and anti-inflammatory activities which explain the basis of its use in traditional medicine to manage pains. It also contains some biologically active constituents worthy of further investigations.

\section{References}

1. Almeida RN, Navarro DS, Barbosa-Filho JM (2001) Plants with central analgesic activity. Phytomedicine 8: 310-322.

2. Akah PA, Nwambie Al (1994) Evaluation of Nigerian traditional medicines: plants used for rheumatic disorder. Journal of Ethnopharmacology 42: 179-182.

3. Dubey NK, Kumar R, Tripathi P (2004) Global promotion of herbal medicine: India's opportunity. Curr Sci 86: 37-41.

4. Shahina-Ghazanfar (1989) Savanna plants an illustrated guide. The Mac Millian press Ltd. Newyork, USA. p: 99.

5. Irvine FR (1958) West African Botany. Oxford University press, London. pp $158-160$

6. Burkhill HM (1985) Useful plants in West Africa. 2nd edn, Royal Botanical Garden, 1: 369-371.

7. Fred-Jaiyesimi A, Onabanjo T, Ademuyiwa $O$ (2008) Phytochemical and Laxative Studies of Globimetula Braunii (Engle) Van Tiegh Growing on Cola Acuminata (Schott \& Endl). Afr J Tradit Complement Altern Med 5: 419-420.

8. Musa MA, Aullahi IM, Muhammad JK, Magaji GM (2014) Phytochemica screening and anticonvulsant studies of ethyl acetate fraction of Globimetula braunii on laboratory animals. Asian Pacific Journal of Tropical Biomedicine 4: 285-289.

9. Olagunju JA, Ismail FI, Gbile ZO (1999) The hypoglycaemic property of norma saline leaf extract of Globimetula braunii in alloxanized diabetic albino rats. Biomed Lett 60: 83-89.

10. Okpuzor J, Ogbunugafor H, Kareem GK (2009) Antioxidant properties of Ethyl Acetate Fraction of Globimetula braunii in Normal Albino Rats. Journal of Biological Sciences 9: 470-475

11. Evans WC (2002) Trease \& Evans pharmacognosy, 15th edn. WR sauders, London, UK. pp: 137-140.

12. Lorke DG (1983) A New Approach to practical acute toxicity testing. Arch Toxicol 54: 275-287.

13. Koster R, Anderson M, Deber EJ (1959) Acetic Acid for Analgesic Screening, Education proceeding, 18: 412.

14. Turner RA (1965) Quantal Responses Calculation of ED50 Screening Methods in Pharmacolgy, Academic Press, New York, USA. pp: 61-63. 
Citation: Atiku I, Sule MI, Pateh UU, Musa AM, Ya'u J, et al. (2015) Phytochemical, Anti-inflammatory and Analgesic Studies of the Crude Ethanolic Leaf Extract of Globimetular brounii Van Tieghem (Family: Loranthaceae). Nat Prod Chem Res 3: 193. doi:10.4172/2329-6836.1000193

Page 4 of 4

15. Winter CA, Riselay EA, Nuss GW (1962) Carrageenan-induced oedema in the hind paw of the rats as an assay for anti-inflammatory drugs. Proc soc Exp Biol Med 111: 544-547.

16. Ramesh M, Rao YN, Rao AVNA, Prabhakar MC, Rao CS, et al. (1998) Antinociceptive and anti-inflammatory activity of a flavonoid isolated from Caralluma attenuate. Journal of Ethnopharmacology 62: 63-66.

17. Rajnarayana K, Sripal Reddy M, Chaluvadi MR (2001) Bioflavanoids Classification, Pharmacological, Biochemical effects and Therapeutic potential. Indian Journal of Pharmacology 33: 2-16.

18. Pari LJ, Umamaheswari J (2000) Antihyperglycaemic activity of Musa sapientum flowers: Effect on lipid peroxidation in alloxan diabetic rats. Phytother Res 14 136-138.

19. Choi J, Jung H, Lee K, Park H (2005) Antinociceptive and Anti-inflammatory effects of saponin and sapogenin obtained from the stem of Akebia quinata. Journal of Medicinal Food 8: 78-85.

20. Ibironke GF, Ajiboye KI (2007) Studies on the anti-inflammatory and analgesic properties of Chenopodium ambrosioides leaf extract in rats. Int Journal of Pharmacology 3: 111-115.
21. Brito ARMS, Antonio MA (1988) Oral anti-inflammatory and anti-ulcero Ora anti-inflammatory and anti ulcerogenic activities of a hydroalcoholic extract and partitioned fractions of Turnera ulmifolia (Turneraceae). J Ethnopharmacol 61 215-228.

22. Just MJ, Recio MC, Geiner RM, Cullar MJ, Manez S, et al. (1998) Antiinflammatory activity of unusual lupane saponins from Buphleurum frutiscescens. Planta medica 64: 404-407.

23. Colier HO, Dinneen LC, Johnson CA, Schneider C (1968) The abdomina constriction response and its suppression by analgesic drugs in mouse. Pharmacology 32: 295-310.

24. Kaneria MS, Naik SR, Kohli RK (2007) Anti-inflammatory, antiarthritic and analgesic activity of a herbal formulation. Indian J Experimental Biol 45: 279 .

25. Sagwan S, Rao DV, Sharma RA (2010) Phytochemical evaluation and quantification of primary metabolites of Maytenus emarginata (Willd.) Ding Hou. J Chem Pharm Res 2: 46-50. 